\title{
AN AYURVEDIC APPROACH OF DUCHENNE MUSCULAR DYSTROPHY - A BRIEF REVIEW
}

\author{
Vd. Suyog P. Bhongare*1, Vd. Vijaykumar U. Gawai² \\ IPG Scholar, Department of Kaumarbhritya, Govt. Ayurved college, Vazirabad, Nanded (Maharashtra), India \\ 2Professor, Department of Kaumarbhritya, Govt. Ayurved college, Vazirabad, Nanded (Maharashtra), India
}

\section{Email: bhongaresuyog@gmail.com,}

\begin{abstract}
Duchenne muscular dystrophy (DMD) is the most common hereditary neuromuscular disease in Indian children affecting all races and ethnic groups. It is a X-linked recessive trait. The abnormal gene is Xp21 locus and is one of the largest genes. Connection of extracellular matrix (ECM) to the cell cortex of muscle and non-muscle cells. ECM-Cell cortex association important for cell strength. Loss of Dystrophin makes cells fragile. Muscle cell and muscle fibres degenerate. Its characteristic clinical features are progressive muscle weakness of mainly proximal lower limb muscles, intellectual impairment, proliferation of connective tissue in muscle, hypertrophy of calves. In Ayurvedic approach it can be classified under Adibalpravrittavyadhi. Pathogenesis occurs due to Beejbhaga Avayavadushti due to which vataprakopa takes place (sthansamshraya) at medomamsadhatu and deplete them. there is no curative treatment to DMD in modern science but according to Ayurveda, Panchkarma, Rasayana, are the important therapy in this disease. Ayurveda do not proclaim as curative but can be used to improve the quality of life of DMD patients.
\end{abstract}

Keywords- DMD, Dystrophin, Adibalpravrittavyadhi, Aampachana, Rasayana 


\section{Introduction}

Duchenne muscular dystrophy (DMD) is the commonest 1 1:3600 male livebirth) hereditary neuromuscular disease in Indian children affecting all races and ethnic groups. It is a X-linked recessive trait. The abnormal gene is Xp21 locus and is one of the largest genes. Connection of extracellular matrix (ECM) to the cell cortex of muscle and nonmuscle cells. ECM-Cell cortex association important for cell strength. Loss of Dystrophin makes cells fragile. Muscle cell and muscle fibers degenerate. This disease is characterized by progressive weakness of mainly proximal lower limb muscles, intellectual impairment, proliferation of connective tissue in muscles, hypertrophy of calves. In Ayurvedic approach it can be classified under

Adibalpravrittavyadhi. Pathogenesis occurs due to Beejbhaga medomamsadhatu and deplete them.

\section{Aims \& Objectives -}

To find out the probable causes of DMD \& its preventive management by Ayurvedic principles.

\section{Material and Methods-}

The data and materials are collected from textbooks of paediatrics, Ayurvedic Samhitas, references from different journals, different practitioners, search results of different websites.

\section{Clinical manifestations -}

1) at birth or early infancy, although some are mildly hypotonic rolling over, sitting and standing are usually achieved at appropriate ages or may be mildly delayed.

3) Poor head control in infancy may be the first sign of weakness.

4) In later childhood, a "transverse" or horizontal smile may be seen.

5) Walking is often accomplished at the normal age but hip girdle weakness may be seen in subtle form as early as $2^{\text {nd }}$ year.

6) Toddlers might assume a lordostic postures when standing to compensate for gluteal weakness.

7) An early 'Gowers sign' is at $3 \mathrm{yr}$. and fully expressed by the age 5 or 6 . A Trendelenburg gait, or hip waddle, appears at this time.

\section{Laboratory findings}

A) Serum creatinine kinase (CK) -

1) Greatly elevated even in presymptomatic stages $(50-100$ times than normal)

2) Normal- $<160 \mathrm{U} / \mathrm{L}$

3) In terminal stages, CK level may be low (less muscle mass due to degeneration)

B) ECG, X-Ray chest, EMG, NCV, Nerve biopsy, USG/MRI, Molecular genetic studies.

\section{Ayurvedic approach-}

According to our classical literature, there is no direct correlation of DMD with any single disease. Hence neuromuscular diseases are

related with vata dosha, can be considered as Adibalapravrittavyadhi. Beejbhag avayava dushti (i.e sex linked disease) leds to some mutation in $\mathrm{X}$ - 
Chromosome, simultaneously there is a formation of Aam leads to Strotorodha, pathetic function of Vata leads Vataprakopa and get Sthansamshraya in Mansa and Medo dhatu, due to this Dhatukshaya occurs. Due to Strotorodha hypertrophy of particular region is occurs. All this results in Duchenne muscular dystrophy.

\section{Ireatment-}

There is no medical cure or method to slow down the progression. Maintain ambulation and prevent contractures is the only way to increase the lifespan of individual. But according to Ayurvedic literature, to breakdown the pathogenesis of the disease, removing the Strotorodha and pacifying the Vatadosha are important.

1) Aampachana- Drugs having properties like Katu, Ushna are useful to proper digestion of Aama, which leads to removing the strotorodha e.g. Panchkola choorna

2) Udavartana- khar, ruksha drugs may be used to udvartana, to remove local strotorodha.

3) Abhyanga- it is useful to nourish the tissue and to strengthen it.

4) Swedana- Pindasweda is very useful to body soft and to remove the stiffness of body and cleanses the strotas and improves the blood circulation in all over body.
5) Basti- It is very important therapy in Ayurveda, according to some physician Basti is 'Ardhachikitsa'. It is best choice of physician to treat the vatavikara.

Brimhan Basti is useful to rejuvenates the degenerative Mamsadhatu.

\section{Conclusion-}

In Duchenne Muscular Dystrophy, where progression of disease is very fast and fatal and no cure is available in modern medicine, the Ayurvedic treatment proved to slow down the progression and bring out a mild improvement.

\section{References-}

1) Ambikkadatta Shashtri, Sushrut Samhita of Sushruta with Ayurveda Tatva Sandipika Hindi commentary, Sutrasthan, reprint edition 2009, chapter no. 24, page no.130

2) Mukesh Agrawal, Textbook of Pediatrics, second edition, page no. 574

3) Kliegman RM, Behrman RE, Jenson HB, Stanton BF, Nelson Textbook of Peditrics, $18^{\text {th }}$ edition, 1456

4) Mukesh Agrawal, Textbook of Pediatrics, second edition, page no. 575

5) Kliegman RM, Behrman RE, Jenson $H B$, Stanton BF, Nelson Textbook of Peditrics, $18^{\text {th }}$ edition , 1457

6) Aruchamy Lakshmanaswamy, Clinical Paediatrics history taking and case discussion, $4^{\text {th }}$ edition, page no. $707-710$ 